\title{
Küçük Menderes Havzası Örneğinde Su Kalitesinde Mevsimselliğin Parametrik Olmayan İstatistiksel Yöntemlerle Değerlendirilmesi
}

\author{
Filiz BARBAROS*1®, Gülay ONUŞLUEL GÜL1® ${ }^{*}$, Hülya BOYACIOĞLU2@
}

${ }^{1}$ Dokuz Eylül Üniversitesi, Mühendislik Fakültesi, İnşaat Mühendisliği Bölümü, 35390, İzmir, Türkiye

2 Dokuz Eylül Üniversitesi, Mühendislik Fakültesi, Çevre Mühendisliği Bölümü, 35390, İzmir, Türkiye

(Alınış / Received: 08.09.2020, Kabul / Accepted: 14.03.2021, Online Yayınlanma / Published Online: 15.08.2021)

\section{Anahtar Kelimeler}

Su kalitesi değişkenleri,

Su kalitesi sinıfları,

Mevsimsellik,

Mann-Kendall eğilim testi,

Küçük Menderes havzası
Özet: Ekolojik dengenin sürdürülebilirliğini sağlamak için en önemli unsurların başında su miktarı ve kalitesi yönetimi gelmekte, bu konuda yürütülen araştırmalar, sürdürülebilir entegre yönetimin ele alındığı her alanda ilgi görmektedir. Su kalitesi gözlemlerinin çeşitli açlardan değerlendirilmesi, karar vericiler için sürdürülebilir su yönetiminin de temel unsurlardan biridir. Meteorolojik, hidrolojik ve insan kaynaklı değişimlerin neden olduğu su kalitesindeki mevsimsel değişikliklerin değerlendirilmesi, yönetim kararlarında kullanılması açısından önem taşımaktadır. Sunulan çalışmada, yoğun tarımsal bölgelerin bulunduğu Küçük Menderes Havzası seçilmiş, bölgenin iklim özelliklerine göre, incelenen dönem soğuk ve sıcak olarak ikiye ayrılarak, yüzeysel su kalitesindeki değişimin incelenmesi ve parametrik olmayan istatistiksel yöntemlerle değişkenlerdeki dönemsel eğilimin ortaya konması amaçlanmıştır. Çalışma sonuçlarına göre, incelenen zaman aralığında havza genelinde organik kirlilik ve azot değișkeni konsantrasyonlarında anlamlı bir artış, çözünmüş oksijen değerinde ise anlamlı bir azalma olduğu izlenmiştir. Yapılan değerlendirmeler ile su kalitesi parametrelerinin mevsimsel değişimlerinin incelenmesinin, kirlilik önleme planlarının hazırlanmasına alt yapı oluşturacağı düşünülmekte; gelecek planlamalara temel oluşturulacak etken unsurların belirlenmesine katkıda bulunulacağ ve benzer şekilde, yönetim, idare ve gözlem sistemi kararlarının değerlendirilmesinde de destek alt yapı olacağı düşünülmektedir.

\section{Evaluation of Seasonality in Water Quality Using Non-Parametric Statistical Methods in the Case of Küçük Menderes Basin}

\section{Keywords}

Water quality variables, Water quality classes,

Seasonality,

Mann-Kendall trend test, Küçük Menderes river basin

\begin{abstract}
Water quantity and quality management are the most important factors in ensuring the sustainability of the ecological balance, and the researches conducted on this issue attract attention in all areas where sustainable integrated management is addressed. Evaluation of water quality observations from various perspectives is also one of the basic elements of sustainable water management for decision makers. Evaluation of seasonal changes in water quality caused by meteorological, hydrological and human-induced changes is important in terms of their use in management decisions. In the presented study, Küçük Menderes Basin, where there are dense agricultural regions, was selected, and the surface water quality parameters was analyzed by non-parametric statistical methods in terms of seasonal changes in surface water quality. Due to the results of the study, it was observed that there is a significant increase in organic pollution and nitrogen variable concentrations, where a significant decrease is observed in dissolved oxygen value throughout the basin during the selected time period. The evaluation of the seasonal variations of the water quality parameters with the evaluations will constitute the infrastructure for the preparation of many pollution prevention plans; contribute to the determination of the factors that will form the basis for future planning, and similarly, it will be a support infrastructure in the evaluation of management, administration and observation system decisions.
\end{abstract}




\section{Giriş}

Su kirliliği, son yıllarda insan toplumu ve doğal ekosistemler için büyüyen bir tehdit haline gelmiştir. Su kalitesi, bir bölgede sürdürülebilir kalkınmayı değerlendirirken dikkate alınması gereken en önemli faktörlerin başında gelmektedir. Çevresel süreçlerin ve dolayısıyla su kalitesinin bozulması, sadece sürdürülebilir kalkınmayı engellemekle kalmayıp, aynı zamanda halk sağlığını da tehdit etmektedir. Ekolojik dengenin sürdürülebilirliğini sağlamak için suyun miktarı ve kalitesi önemlidir. Bu nedenle, su kalitesinin izlenmesine dayanan araştırmalar, sürdürülebilir entegre yönetimin ele alındı̆̆ı her ortamda daha da ilgi görmekte ve farklı yaklaşımlar ile su kalitesi değişkenlerinin eğilimleri detaylı bir şekilde incelenebilmektedir.

Su kalitesi gözlemlerinin çeşitli açılardan değerlendirilmesi, karar vericiler için sürdürülebilir su yönetiminde alt yapı olarak kullanılacak temel araçlardan biridir. Bu amaçla, yüzeysel su kalitesinin değerlendirilmesi adına birçok çalışma yapılmış ve yapılmaktadır. Bunların bir kısmında, entegre havza yönetimi çerçevesinde, su kalitesi değişkenlerinin ilgili çalışmalardaki gözlem periyodlarında, mevcut bir eğilim olup olmadığı incelenirken [1-3]; bir kısmında da, su kalitesi indisi temelinde, yüzeysel su kalitesi değerlendirilmektedir. Gözlem yapılan dönem boyunca, nehir havzasının özelliklerine bağlı olarak seçilen su kalitesi değişkenleri için, "su kalitesi indisi" temelinde yapılan değerlendirmeler, yüzeysel su kalitesi hakkında karar vericiler için bir alt yapı oluşturmaktadır [4-9]. Çalışma alanları farklı olsa da, temel su kalitesi değişkenleri olarak, çalışmaların birçoğunda seçilen değişkenlerin benzerlik göstermekte olduğu ve seçilen değişkenlerin genellikle sıcaklık, pH, bulanıklık, çözünmüş oksijen (ÇO) ve biyokimyasal oksijen ihtiyacı (BOİ) olduğu tespit edilmiştir. Su kalitesi indisi değerlendirilmeleri ile yüzeysel suların çeşitli amaçlarla sinıflandırılmasına izin verilmekte ve yönetim stratejilerini değerlendirmek için bir kıyaslama düzlemi sağlanmaktadır. Diğer yandan, yapılan bu çalışmalar incelendiğinde; ÇO ölçümünün, organik kirlilik derecesinin ve suyun kendi kendini arıtabilme seviyesinin belirlenmesinde kullanılmasına değinilmiş, ÇO ile BOİ arasında belirgin bir ilişki olduğu ortaya konmuştur [7].

İklim değişikliğinin su miktarı üzerindeki temel etkilerinden olan taşkın ve kuraklık, niceliksel etkilerin yanında yüzeysel su kalitesini de etkilemektedir. Son yıllarda yapılan çalışmalar ile su sektörünü etkileyen faktörlerden sadece bir tanesi olan iklim değişikliğinin su kalitesi üzerine etkileri de incelenmiştir. Normal ve kurak geçen dönemler arasındaki farklar; bu değişimlerin su kaynakları, içme, kullanma ve yüzeysel su kalitesi ile noktasal kirlilik üzerine etkileri yapılan çalışmalar ile incelenmiştir. İklim değişikliğinin, su kalitesi üzerinde etkisinin olacağı, kurak dönemlerde su sıcaklığında bir değişiklik gözlenmese de, ÇO miktarında düşüş olacağı; artan sıcaklık ve yağıșın, pH ve ÇO'yu doğrudan etkileyeceği ortaya konmuştur [10-13]. İklim değişikliğinin etkilerinin incelenmesinde, artan ve azalan eğilimler ile birlikte mevsimsel ve bölgesel değişimlerin de incelendiği çalıșmalar mevcuttur [1419]. Meteorolojik koşullardaki değişimlerin, su kalitesi değişkenleri ile olan ilişkilerinin ortaya konması da gelecek senaryolarının oluşturulmasında karar vericilere alt yapı oluşturacak bir başka unsurdur.

Bu amaçla, su kalitesindeki mevsimsel değișikliklerin değerlendirilmesi, yüzeysel su kirliliğinin zamansal değişimlerini değerlendirmek için önemlidir. Her mevsimdeki yüzeysel suyun kimyasal bileşimi, çözünme, seyrelme ve antropojenik nedenler ile kaya-su etkileşimlerinden güçlü bir şekilde etkilenmekte [20] ve bu nedenle su kalitesindeki mevsimsel değişimin incelenmesi büyük önem taşımaktadır. Mevsimsel değișimin incelendiği çalıșmaların bir kısmında mevsimler geleneksel şekilde ayrilırken (Illkbahar = Mart, Nisan, Mayıs; Yaz = Haziran, Temmuz, Ağustos; Sonbahar = Eylül, Ekim, Kasım; Kış = Aralık, Ocak, Şubat), bir kısmında ise çalışmanın yapıldığı bölgedeki iklim koşullarına göre özel sınıflandırılmaların (Kıș = Aralık Şubat; Yaz = Haziran- Ağustos) yapıldığı görülmüştür [20-22]. Yüzeysel su kalitesinin değerlendirilmesi için dünya çapında yapılan çalışmaların benzerleri, ülkemiz nehirleri için de uygulanmış ve su kalitesi parametrelerinin eğilimleri ve farklı kullanım amaçları için su kalitesinin mevcut durumu irdelenmiştir [23-26].

Çeşitli çalışmalarda su kalitesi verilerinin normal dağılıma uymaması nedeniyle genellikle eğilimlerin belirlenmesinde parametrik olmayan yöntemler kullanılmıştır. Bu çalışmanın amacı da, yüzeysel su kalitesindeki mevsimselliği, yüzeysel su miktarlarının dönemsel farklılıklarını temel alarak, parametrik olmayan istatistiksel yöntemlerle değerlendirerek, havza yönetiminde karar vericiler için dönemsel değişikliklerin etkilerinin de göz önüne alınabileceği alternatif bir değerlendirme yöntemi sunmaktır. Önerilen yöntem, Küçük Menderes Havzası örneğinde, mevsimselliğin etkisinin incelenmesi amacı ile akım miktarlarının farklı olduğu dönemler ayrı ayrı değerlendirilmek üzere su kalitesi verilerine uygulanmıştır.

\section{Küçük Menderes Havzası}

Küçük Menderes Havzası, $38^{\circ} 41^{\prime} 05^{\prime \prime}$ ve $37^{\circ} 24^{\prime} 08^{\prime \prime}$ kuzey enlemleri ile $28^{\circ} 24^{\prime} 36^{\prime \prime}$ ve $26^{\circ} 11^{\prime} 48^{\prime \prime}$ doğu boylamları arasında yer almaktadır. Türkiye'nin yüzölçümünün yaklaşık \% 0,90 'lı bir kısmını kapsayan ve 702.931 ha'lık bir alana sahip Küçük Menderes Havzası, İzmir ilinin büyük bir kısmını, Aydın iline bağlı olan Kuşadası ilçesi ve Manisa ilinin de küçük bir kısmını sınırları içine alır. Havza, güney ve doğudan Büyük Menderes Havzası'na, kuzeyden Gediz Havzası'na komşu; batısı ise Ege Denizi ile çevrilidir. 2020 yılı Türkiye İstatistik Kurumu (TÜİK) 
verilerine göre Küçük Menderes Havzası toplam nüfusu 3.600 .000 kișidir. $3.225 \mathrm{~km}^{2}{ }^{\prime} l i k$ yağıș alanından oluşan yıllık ortalama yağıș miktarı 622 $\mathrm{mm}$, yıllık ortalama akış ise $1,45 \mathrm{~m}^{3} / \mathrm{s}^{\prime} \operatorname{dir}$ [27].

Küçük Menderes Havzası'nı oluşturan İzmir, Aydın ve Manisa illeri ekonomileri ile sanayiye, tarıma ve turizme oldukça büyük katkıları bulunmaktadır. Havzada başta tarım olmak üzere, su kaynaklarına etkisi olan faaliyetler; hayvancllk, sanayi ve turizm faaliyetleridir [27-30].

Havzada, \% 52'sinde sulu, \% 48'lik kısmında ise susuz olmak üzere, toplam 314.137 ha alanda tarım yapılmaktadır [27]. Tarımsal amaçlı sulamalar halk sulamaları, DSİ sulamaları ve il özel idare sulamaları olarak ayrilmakta ve toplamda 172.811 ha alan sulanmaktadır [28-29]. Hayvancılık faaliyetleri, küçükbaş ve büyükbaş ile kümes hayvancıllı̆̆l, ipekböcekçiliği, arıcılık ve su ürünleri yetiştiriciliği olarak sınıflandırılmaktadır [31]. Havzada adı geçen hayvancılı faaliyetlerinden oluşan su tüketimleri, İller Bankası'na göre, her bir küçükbaş hayvan için 15 l/g, büyükbaş hayvan için ise $50 \mathrm{l} / \mathrm{g}$ şeklindedir. Küçük Menderes Havzası'ndaki mevcut iki adet organize sanayi bölgesi ve iki adet enerji santralinin yanı sıra birçok tekil sanayi firmaları; her endüstri sektörüne özgü su kullanım miktarları ile havza su bütçesine katkıda bulunmaktadır. Tanımlanan tüm faaliyet alanlarının içinde, diğerlerine oranla daha düşük bir orana sahip olan turizm sektörünün havza su bütçesine katkısı turistik bölgelerdeki konaklama bölgelerinden alınan güncel bilgiler ile hesaplanmaktadır [29].

Küçük Menderes Havzası'na deşarj edilen toplam atıksu miktarı günlük yaklaşık 109.000 m³'tür. Havza içerisine deşarj edilen toplam atıksu miktarının yaklaşık \%75'i kentsel, $\% 25$ 'i ise endüstriyel niteliklidir. Toplam atıksu miktarının \%23'lük kısmı ise arıtılmadan deşarj edilmektedir. Noktasal kirlilik kaynaklarının yanı sıra havzada mevcut yayll kirletici parametreleri azot ve fosfor gibi besi maddeleridir ve bu kirlilik yükleri baskın olarak tarımsal faaliyetlerden ve hayvan yetiştiriciliğinden kaynaklanmaktadır [31-32].

Küçük Menderes Havzası, Şekil 1'de görülen 5 adet alt havzadan oluşmakta ve yukarıda özetlendiği şekilde su kaynaklarına etkisi olduğu ortaya konan temel faaliyetlerin havza çapında gösterildiği 2012 yılına ait arazi kullanım haritası da Şekil 2'de verilmektedir.

Küçük Menderes Havzası'nda yaşanan çevresel sorunlar nedeniyle, yüzeysel ve yeraltısuları ile deltası her geçen gün kirlenmekte ve ekolojik denge bozulmaktadır. Havzada 2001-2003 yıllarında yapılan bir çalışmada, nehir suyundan alınan örneklemeler ile mevcut kirlilik değerlendirilmeye çalışılmış ve nehir suyu kalitesinin genel olarak III. ve IV. sınıf (Kirli ve Çok Kirli Sular) su kalitesinde olduğu tespit edilmiştir. [33].

2009 yılında yapılan bir başka çalışmada, Küçük Menderes deltası incelenmiş ve havzadaki değișimlerden doğrudan etkilendiği, yaklașık 26.000 ha sulak alanın kurutularak tarımsal kullanıma açıldığı belirtilmiştir. Deltadaki su sisteminin büyük oranda etkilendiği ortaya konmuștur. Diğer taraftan, havzadaki yoğun insan faaliyetleri ile ciddi bir degradasyonal etkinin oluştuğu, dolayısıyla da artan bir kirlilik gözlemlendiği ifade edilmiştir [34]. Deltada yapılan bir başka çalışmada ise deltanın çevresel morfolojisi incelenmiş ve benzer sorunlara değinilmiștir [35].

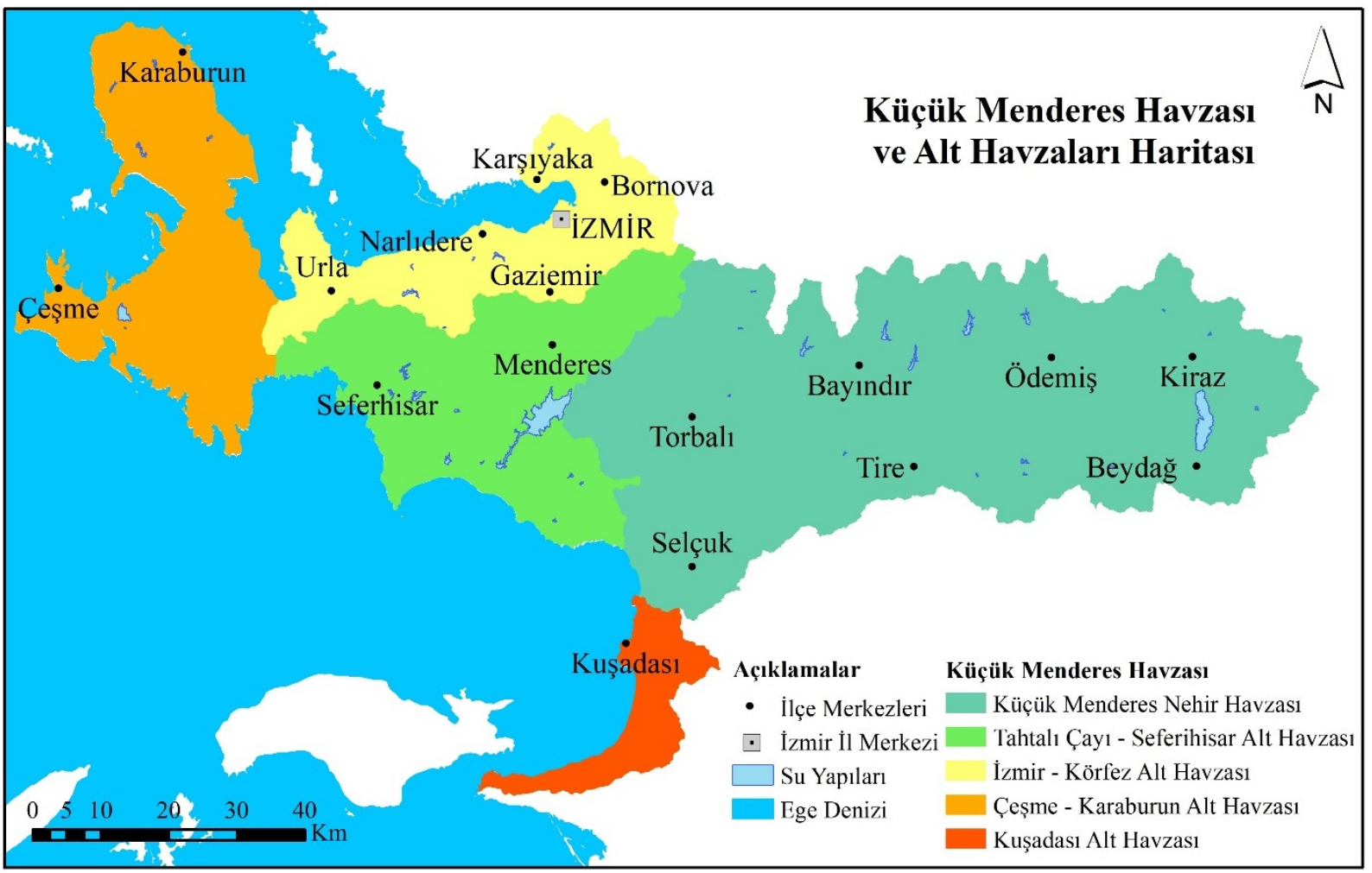

Şekil 1. Küçük Menderes Havzası ve Alt Havzaları. 


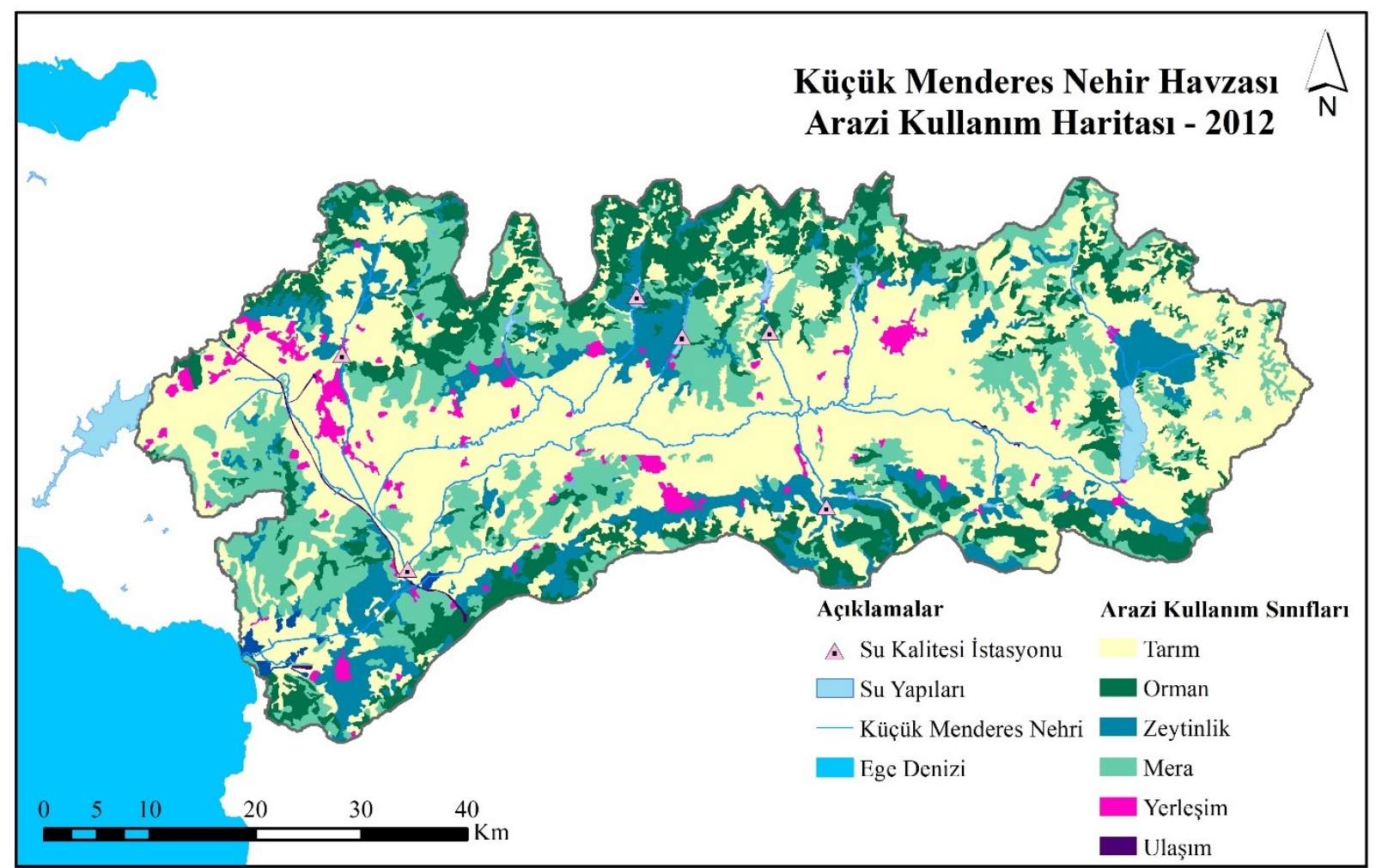

Şekil 2. Küçük Menderes Nehri Arazi Kullanım Haritası - 2012.

Çeșitli çalışmalarla ortaya konan Küçük Menderes Havzası'ndaki çevresel sorunlara temel olușturmak üzere, TÜBİTAK Marmara Araștırma Merkezi Çevre Enstitüsü tarafından 2010 yılında Çevre ve Orman Bakanlığı'nca desteklenen, Havza Koruma Eylem Planlarının hazırlanması kapsamında, Küçük Menderes Havzası projesi hazırlanmıștır. Proje ile sürdürülebilir havza yönetim anlayıșıyla yeni bir yapılandırmanın gerekliliği vurgulanmış ve çerçevesi çizilen yeni sistemin hayata geçirilmesi belirtilmiştir [31].

Çevre ve Şehircilik Bakanlığı, Çevre Yönetimi Genel Müdürlüğü tarafından 2016 yılında hazırlanan "Küçük Menderes Havzası Kirlilik Önleme Eylem Planı" 'nda, havzada artan nüfus, endüstriyel, hayvancıllk ve tarım faaliyetleri ile yapılan değerlendirmeler sonucunda, Küçük Menderes Havzası'nda su kalitesinin genel olarak IV. sınıf olduğu ve noktasal kirlilik deşarjlarının kontrolü amacı ile çeşitli yatırımların planlandığı belirtilmiştir [32].

Tarım ve Orman Bakanlı̆̆ Su Yönetimi Genel Müdürlüğü'nce 2018 yllında hazırlanan Küçük Menderes Nehir Havzası Yönetim Planı'nda ise havzadaki sorunlar güncel şekilde ele alınmış ve iklim değişikliğinin de dikkate alındığ çeşitli hedefler belirlenmiştir [36]. Aynı yıl yapılan başka bir çalışmada ise havzadaki üreticiler açısından iklim değişikliğinin olası etkileri tartışılmıştır [37]. 2018 yılında yapılan çalışma ile Taşkın ve Kuraklık Yönetimi Dairesi Başkanlığı, "Küçük Menderes Havzası Kuraklık Yönetim Planı" 'nı hazırlanmıș ve kuraklık sorunu detaylı bir şekilde ele alınmıştır [28-30]. 2019 yılında ise Su Yönetimi Genel Müdürlüğü, Küçük Menderes Havzası Nehir Havza Yönetim Planı Hazırlanması
Projesi kapsamında, "Nehir Havza Yönetim Planı Nihai Raporu" 'nu yayınlamıs ve bu rapor ile mevcut baskı ve etkilere yönelik çözüm, öneri ve tedbirler sunulmuştur [30].

Sunulan çalışma kapsamında, Küçük Menderes Nehir alt havzasında izleme çalıșmaları kapsamında alınan su örneklerinden analizi yapılan fiziksel parametreler "pH", "sıcaklık", "çözünmüş oksijen (ÇO)", "nitrat $\left(\mathrm{NO}_{3}\right)$ azotu" ve "amonyum $\left(\mathrm{NH}_{4}\right)$ azotu" ile organik parametrelerden "biyokimyasal oksijen ihtiyacı (BOI)"'nı içeren veri setleri değerlendirilmiștir.

$\mathrm{pH}$, bir çözeltinin asidik/bazik olma durumunun şiddetini gösterir ve kimyasal işlemlerde çökelebilirliğe etki ederken, biyolojik işlemlerde ise organizma aktivitesini etkiler. Organizma aktiviteleri de doğrudan ÇO ve BOİ ile bağıntılıdır. ÇO, yüzeysel sularda organik kirliliğin en önemli göstergelerinden biridir; sudaki oksijen miktarı; atmosferdeki oksijenin kısmi basıncına, su sıcaklığına, suya oksijen kazandıran organizmalara ve sudaki mineral konsantrasyonuna bağlıdır. Kirli sulardaki çözünmüș oksijen biyolojik faaliyetlerle hızla azalır, BOİ ise aynı hızla artar. BOİ atık sudaki organik maddeyi dengelemek üzere, aerobik koşullar altında, bakterileri parçalamak için mikroorganizmalar tarafından kullanılan oksijen miktarını ifade eder [38].

Atıksularda azot pH'a göre, reaksiyonu Eş. 1'de verildiği șekilde, amonyum iyonu $\left(\mathrm{NH}_{4}^{+}\right)$ya da amonyak $\left(\mathrm{NH}_{3}\right)$ halinde bulunur;

$$
\mathrm{NH}_{3}+\mathrm{H}_{2} \mathrm{O} \leftrightarrow \mathrm{NH}_{4}^{+}+\mathrm{OH}^{-}
$$


$\mathrm{pH} \geq 7$ olduğunda denge sola doğru bozulmakta; $\mathrm{pH} \leq 7$ olduğunda ise amonyum iyonları ortamda mevcut olduğundan; ortamdaki $\mathrm{NH}_{3}$ veya $\mathrm{NH}_{4}{ }^{+}$'ten hangisinin oluşacağını $\mathrm{pH}$ belirlemektedir [39]. Aerobik ortamda bakteri faaliyeti sonucu amonyak oksitlenerek nitrit ve nitrat haline gelir. Nitrit kararsızdır ve kolaylıkla nitrata dönüşür [38, 40]. Dolayısıyla asidik durumlarda $\mathrm{NH}_{4}{ }^{+}$ miktarı ve yeterli miktarda oksijen bulunması durumuna bağlı olarak da nitrat azotu miktarında artış gözlenecektir.

Çalışmanın amacı, bu temel bilgiler çerçevesinde, su kalitesi gözlem değerlerini, eğimlerini ve ayrıca mevsimsel farklılıklarını istatistiksel olarak değerlendirerek; a) havza su kalite sınıflarını belirlemek, b) eğilim analizi ile zamansal değișimini ortaya koymak ve c) havzada yönetim uygulamalarındaki etkinliğini değerlendirmektir.

\section{Yöntem}

Çalışmada su kalitesi gözlem istasyonlarındaki su kalitesi veri setleri konu ile ilgili benzer çalışmalardaki örnekler [3, 4, 9, 20] ile bölgenin hidrolojik özellikleri dikkate alınarak, mevsimsel farklılıkları da temsil edecek șekilde aşağıdaki gibi iki döneme ayrılmıștır:

a. Soğuk Dönem (Kasım, Aralık, Ocak, Şubat ve Mart),

b. Sıcak Dönem (Nisan, Mayıs, Haziran, Temmuz, Ağustos, Eylül ve Ekim).

Tanımlanan her iki döneme ait su kalite verilerinin tanımlayıcı istatistikleri hesaplanarak, su kalite sınıfları belirlenmiş; eğilim testleri ile de kalite değişkenlerinin zamansal değişimi ortaya konmuştur.

Kalite gözlem istasyonlarından alınan örneklerde analizi yapılan su kalitesi değişkenlerinin bu dönemlere ait eğilim testleri, parametrik olmayan Mann-Kendall Sira Korelasyon testi ile gerçekleştirilmiştir.

\subsection{Mann-Kendall Testi}

Özellikle ölçüm dönemi içinde eksik verileri olan zaman serilerine uygulanan Mann-Kendall testi, hidrometeorolojik zaman serilerinde görülebilecek artma veya azalma eğilimindeki gidişlerin önemini istatistiksel olarak ortaya koyma açısından sıklıkla uygulanan bir testtir [43]. Mann-Kendall testinde, $n$ veri uzunluğu olmak üzere, i $=1, \ldots, n-1$ 'e kadar sıralanmış olan $\mathrm{x}$ veri seti ile $\mathrm{j}=\mathrm{i}+1, \ldots$, n'e kadar sıralanmış olan $\mathrm{x}_{\mathrm{j}}$ veri seti Eş. 2'ye göre karşılaştırılır.

$$
\operatorname{sgn}\left(x_{j}-x_{i}\right)=\left\{\begin{array}{c}
1 ; x_{j}>x_{i} \\
0 ; x_{j}=x_{i} \\
-1 ; x_{j}<x_{i}
\end{array}\right.
$$

Mann-Kendall test istatistiği, $S$ istatistiği Eş. 3 kullanılarak hesaplanmaktadır.

$$
S=\sum_{i=1}^{n-1} \sum_{j=i+1}^{n} \operatorname{sgn}\left(x_{j}-x_{i}\right)
$$

Yukarıdaki eşitlik ile hesaplanan S değeri, n sayısı 8'den büyük olduğunda yaklaşık olarak normal olarak dağılır, $n \geq 30$ olduğunda, t testi $\mathrm{Z}$ testine yaklaşır [44]. $\mathrm{S}$ değerinin ortalaması ve varyansı sırasıyla Eş. 4'de verilmiştir.

$$
\begin{gathered}
E[S]=0 \\
\sigma^{2}=\frac{n(n-1)(2 n+5)-\sum_{j=1}^{r} t_{j}\left(t_{j}-1\right)\left(2 t_{j}+5\right)}{18}
\end{gathered}
$$

Burada; r, veri kümesindeki tekrar eden veri gruplarının sayısı ve $t_{j}$, j. tekrar eden veri grubundaki veri sayısıdır.

Standartlaștırılmıș Mann-Kendall istatistiği Z, Eş. 5 ile verilmektedir. İncelenen seride, eğilim yoktur $\mathrm{H}_{0}$ hipotezi varsayımında ortalaması sıfır, varyansı 1 olan standart normal dağılım göstermektedir.

$$
Z=\left\{\begin{array}{cc}
(S-1) / \sigma_{S} & S>0 \\
0 & S=0 \\
(S+1) / \sigma_{S} & S<0
\end{array}\right.
$$

Hesaplanan $\mathrm{Z}$ değeri, mutlak değerde $\mathrm{Z}_{(\alpha / 2)}$ 'den küçük olduğunda, eğilim olmadığı yönündeki sıfır hipotezi kabul edilir, aksi takdirde reddedilir. Pozitif ve negatif Z değerleri, sırasıyla artan ve azalan bir eğilimi temsil eder. Sirasıyla $\alpha=0,05$ ve $\alpha=0,1$ anlamlılık seviyelerine eşit olan Z değerleri (1,96 ve 1,64) kullanılarak tespit edilen eğilimler sınıflandırılabilmektedir [45].

\subsection{Sen'in Eğilim Eğim Metodu}

Sen (1968), $n$ adet veri çiften oluşan bir örnekte eğiliminin eğimini tahmin etmek için parametrik olmayan bir yöntem geliștirmiştir. Bu yöntem, zaman serisinde lineer bir eğilim mevcut ise eğimin (birim zamandaki değişimin) belirlenmesine olanak sağlamakta, ölçüm hatalarından veya uç değerlerden etkilenmeyen ve eksik değerlerin bulunduğu veri setlerine uygulanabilmektedir [46-49].

Sen'in yöntemi, eğilimin eğimini tahmin etmek için doğrusal bir model kullanmaktadır. Kalıntıların varyansı aşağıdaki gibi hesaplanan zaman aralığında sabit olmalıdır.

$$
Q_{i}=\frac{X_{j}-X_{k}}{j-K} \quad \mathrm{i}=1 \ldots, \mathrm{n}
$$

Burada; $X_{j}$ ve $X_{k}$ sırasıyla j ve k (j> k) zamanlarındaki veri değerleridir. Her zaman periyodunda yalnızca bir veri varsa, o zaman $\mathrm{N}=\mathrm{n}(\mathrm{n}-1) / 2$ bir veya daha fazla zaman diliminde birden fazla gözlem varsa bu durumda $\mathrm{N}<\mathrm{n}(\mathrm{n}-1) / 2$ olmaktadır. $Q_{i}$ 'nin değerleri en 
küçükten en büyüğe sıralanır ve eğimin medyanı veya Sen'in eğim tahmini aşağıdaki gibi hesaplanır.

$$
Q_{\text {med }}= \begin{cases}Q_{\left[\frac{N+1}{2}\right]^{\prime}} & N \text { tek ise } \\ \frac{Q_{\left[\frac{N}{2}\right]}+Q_{\left[\frac{N+2}{2}\right]}}{2}, & N \text { çift ise }\end{cases}
$$

$Q_{m e d}$ 'in işareti verilerin eğilim yönünü yansıtırken, değeri eğilimin dikliğini göstermektedir. Medyan eğiminin istatistiksel olarak sıfırdan farklı olup olmadığını belirlemek için, belirli bir olasılıkta $Q_{m e d}$ 'in güven aralığı elde edilmelidir. $\mathrm{Bu}$ güven aralığı aşağıdaki gibi hesaplanabilir [50].

$$
C_{\alpha}=Z_{1-\alpha / 2} \sqrt{\operatorname{Var}(S)}
$$

Burada; $\operatorname{Var}(S)$, (4) denklemi ile hesaplanan $\mathrm{S}$ değerinin varyansıdır. $Z_{1-\alpha / 2}$ ise normal dağılım tablosundan elde edilmektedir.

Sunulan çalışmada $\alpha=0,05$ alınarak hesaplamalar gerçekleştirilmiştir. Eğilim testleri sonuçlarında ortaya çıkan anlamlı artan ve azalan eğilim sonuçları üzerinden Sen'in Eğilim Eğim Metodu kullanılarak hesaplanan eğim değerleri ile havzada su kalitesi açısından en kritik bölgeler belirlenmiştir.

\section{4. Çalışma Sonuçları}

Sunulan çalışmada, Küçük Menderes Nehir Havzası'nda konumları Şekil 3'de verilen 6 adet gözlem noktasına ait (A, B, C, D, E ve F) veriler soğuk ve sıcak dönemlere ayrılarak ayrı ayrı değerlendirilmiştir. Her iki döneme ait akım değerleri tanımlayıcı istatistikleri Tablo 1'de; 1985-2018 yılları arasında yapılan su kalitesi izleme çalışmalarında gözlem istasyonlarında analizi yapılan 6 kalite değișkenine ait hesaplanan ortalama, medyan, standart sapma ve çarpıklık katsayısı içeren tanımlayıcı istatistikler ise Tablo 2'de sunulmuştur.

Tablo 1. Soğuk ve Sıcak Dönemler için Akım Değerlerinin Tanımlayıcı İstatistikleri.

\begin{tabular}{ccc}
\hline & Sicak Dönem & Soğuk Dönem \\
\hline Minimum & 0 & 0 \\
Maksimum & 75,73 & 144,09 \\
Ortalama & 3,70 & 17,65 \\
St. Sapma & 7,34 & 22,49 \\
Medyan & 1,03 & 9,13 \\
\hline
\end{tabular}

Her istasyondaki su kalitesi değişkenlerine ait veri setleri, öncelikle zamana göre değerlendirilerek, veri seti dağılımları grafiksel olarak incelenmiștir. $6 \mathrm{su}$ kalitesi değişkeni için 6 istasyondaki verilerin gidişi belirlenmiștir. $\mathrm{Bu}$ grafiklerden, sunulan çalıșma kapsamında örnek olarak, C istasyonuna ait, ÇO değişkeninin zamana ve dönemlere göre değişimi Şekil 4'te verilmiştir.

Elde edilen tüm grafiklerdeki zaman serileri "Su Kalitesi Sinıflandırılması" limitlerine göre incelendiğinde, 2000'li yılların başından günümüze kadar geçen önemde önemli bir artış olduğu izlenmiştir. Bu durum, genel olarak, artan nüfus artışı, insani ve endüstriyel faaliyetlerin alıcı ortamlara olan olumsuz etkileri olarak ortaya konmakta; bölgeler ve değişkenler özelinde gözlenen değişimler ise akarsuya gelen kirlilik yüklerindeki artışlar ile birlikte meteorolojik koşullardaki değișikliklerin sucul ortamdaki yaşama olan olumsuz etkileri ile açlklanabilmektedir.

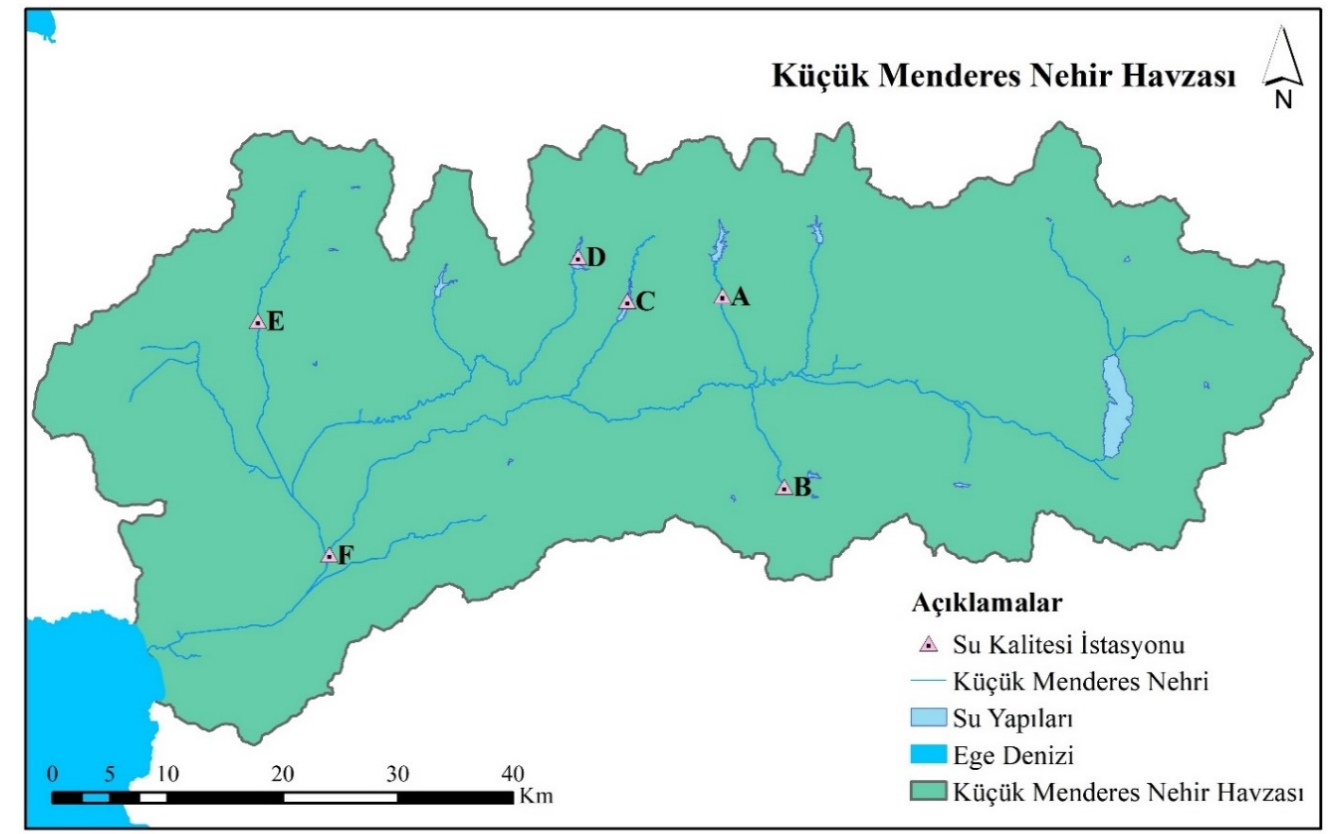

Şekil 3. Çalışma Alanı ve ilgili Su Kalitesi Gözlem İstasyonlarının Konumu. 
Tablo 2. Soğuk ve Sıcak Dönemlere ait incelenen Su Kalitesi Değișkenlerinin Tanımlayıcı İstatistikleri.

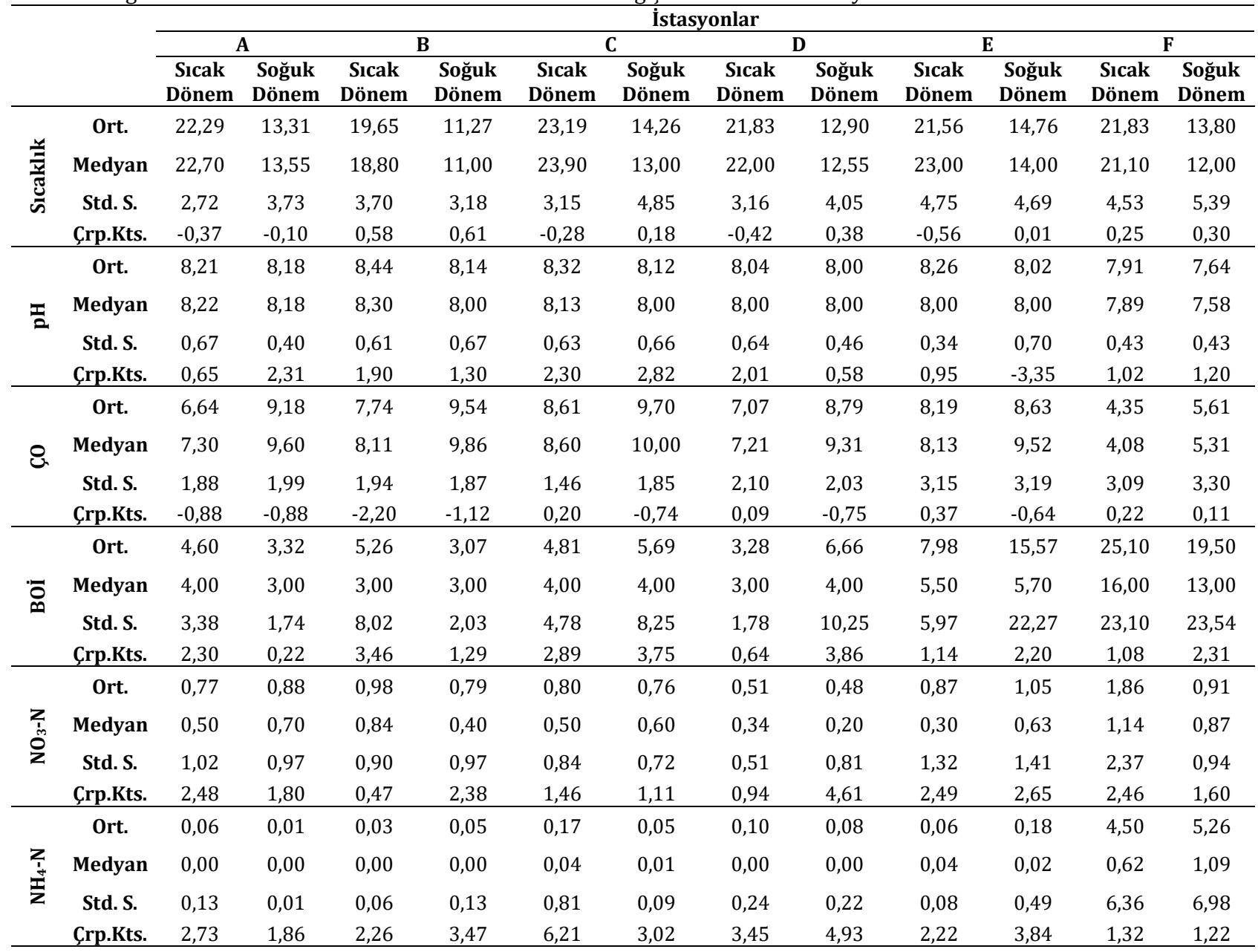

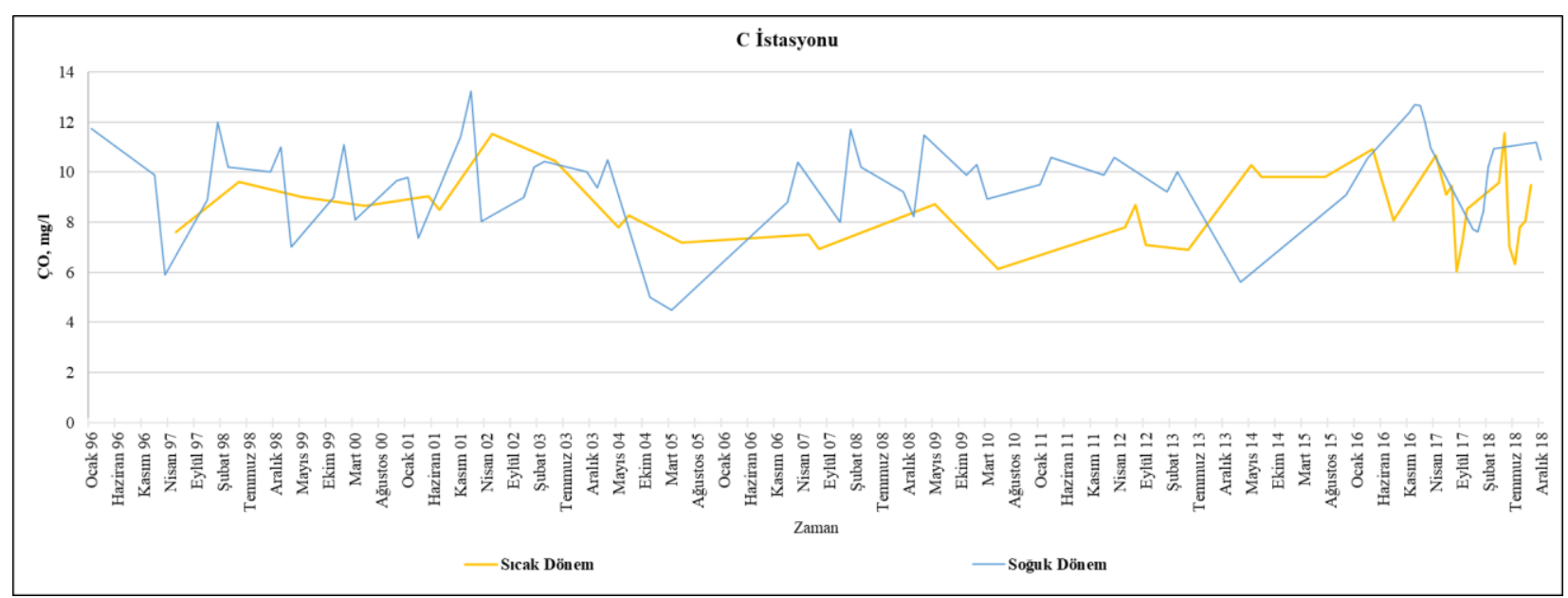

Şekil 4. ÇO için Sıcak ve Soğuk Dönem Gidişleri.

Çalışmada, bir sonraki aşamada, su kalite sınıflarının belirlenmesi için veri setlerinin $\% 90$ değerleri hesaplanmıștır. Bu değerler, 31/12/2004 tarihli ve 25687 sayılı Resmi Gazete'de yayımlanan ve 2008 yılında güncellenmesinin ardından, Çevre ve Şehircilik Bakanlığı'nın 2019 yılında en son hali ile yürürlükte bulundurduğu "Su Kirliliği Kontrolü Yönetmeliği”'nin "Kıta içi Su Kaynaklarının Sinıflarına Göre Kalite Kriterleri" su kalite sınıflandırmaları tablosuna göre, seçilen değişkenler özelinde Tablo 3'te verilen su kalite sınıfı limitlerine göre kıyaslanarak su kalite sınıfları belirlenmiștir [41-42]. İstasyonlarda her değişkenin \%90 değerlerine göre belirlenen farklı dönemlerdeki su kalite sınıfları Şekil 5 ile 9 arasında görülmektedir.

pH değerlerine bakıldığında su kalitesinin genelde III. ve IV. sınıf olduğu görülmektedir (Şekil 5). pH değerleri düşük akım koşullarından daha olumsuz etkilenmektedir. Yüzeysel sudaki ÇO miktarının azaldığı tüm kısımlarda, BOİ miktarlarının arttığı gözlenmektedir (Şekil 6 ve 7). Alıcı ortamdaki kirlilik 
sonrası, sudaki mevcut oksijen mikroorganizmalar tarafından bakterileri parçalamak üzere kullanılmakta ve doğal ortamdaki organik madde dengesi sağlanmaktadır. Genellikle düşük akım dönemlerinde BOİ açısından havzadaki su kalitesi III. ve IV. kalite sınıfına aittir. Yüksek akım koşullarında seyrelme etkisi ile iyileşme gözlenmektedir. Membada bulunan istasyonlarda kalitenin mansaba göre daha iyi olması arazi kullanım haritasında da görüldügü üzere (Şekil 2), o bölgedeki tarımsal ve endüstriyel faaliyetlerin daha az olması ile açıklanabilir.

Tablo 3. Su Kalitesi Değişkenleri için Su Kalite Sınıf Limitleri [41-42].

\begin{tabular}{|c|c|c|c|c|}
\hline \multirow{2}{*}{ Su Kalite Değişkenleri } & \multicolumn{4}{|c|}{ SU KALİTE SINIFLARI } \\
\hline & I & II & III & IV \\
\hline Sicaklık ( $\left.{ }^{\circ} \mathrm{C}\right)$ & 25 & 25 & 30 & $>30$ \\
\hline pH & $6,5-8,5$ & $6,5-8,5$ & $6,0-9,0$ & $6,0-9,0$ dişında \\
\hline Çözünmüş Oksijen (mg On2/L) & 8 & 6 & 3 & $<3$ \\
\hline Amonyum Azotu (mg NH $\left.4^{+-} / \mathrm{L}\right)$ & $0,2^{c}$ & $1^{c}$ & $2^{c}$ & $>2$ \\
\hline Nitrat Azotu (mg NO$\left.{ }_{3}^{-}-\mathrm{N} / \mathrm{L}\right)$ & 5 & 10 & 20 & $>20$ \\
\hline Biyolojik Oksijen İhtiyacı (BOİ) (mg/L) & 4 & 8 & 20 & $>20$ \\
\hline
\end{tabular}

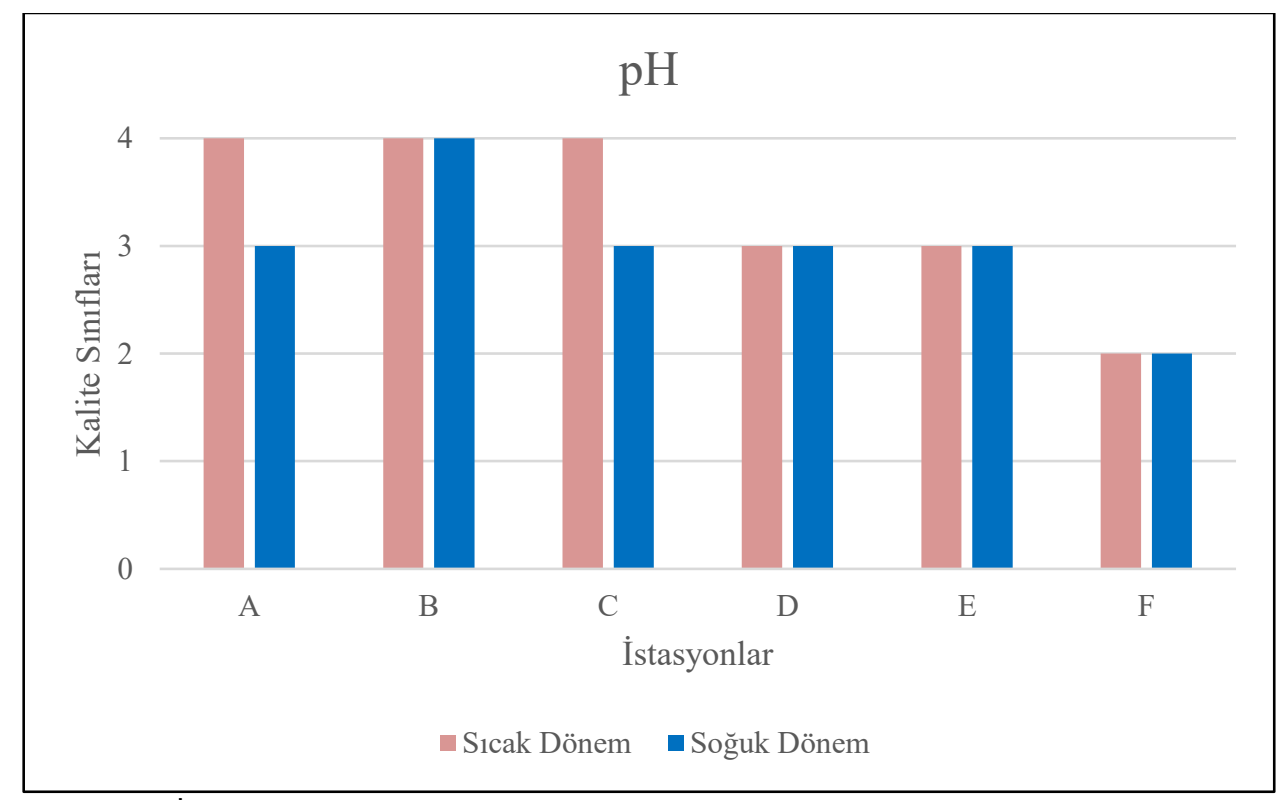

Şekil 5. Su Kalitesi Gözlem İstasyonlarındaki pH Değişkenine ait Su Kalite Sınıfları.

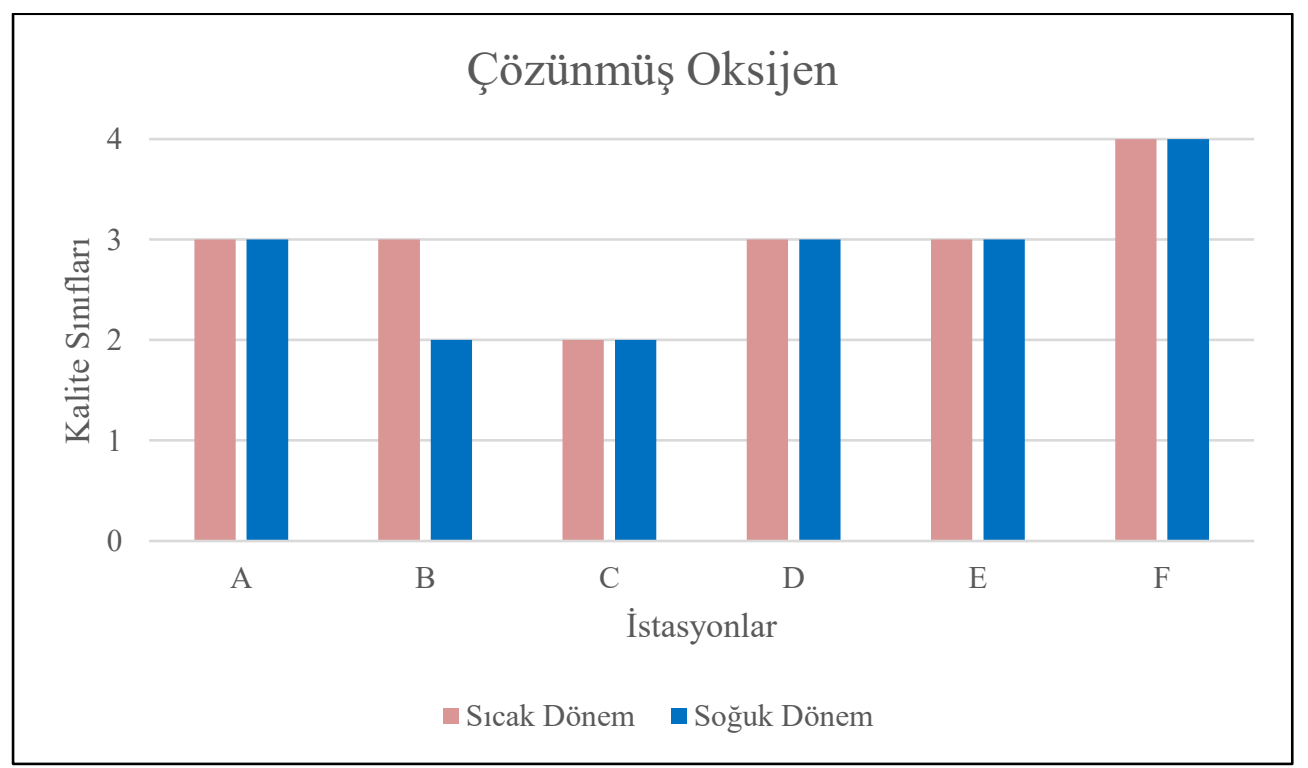

Şekil 6. Su Kalitesi Gözlem İstasyonlarındaki ÇO Değişkenine ait Su Kalite Sınıfları. 


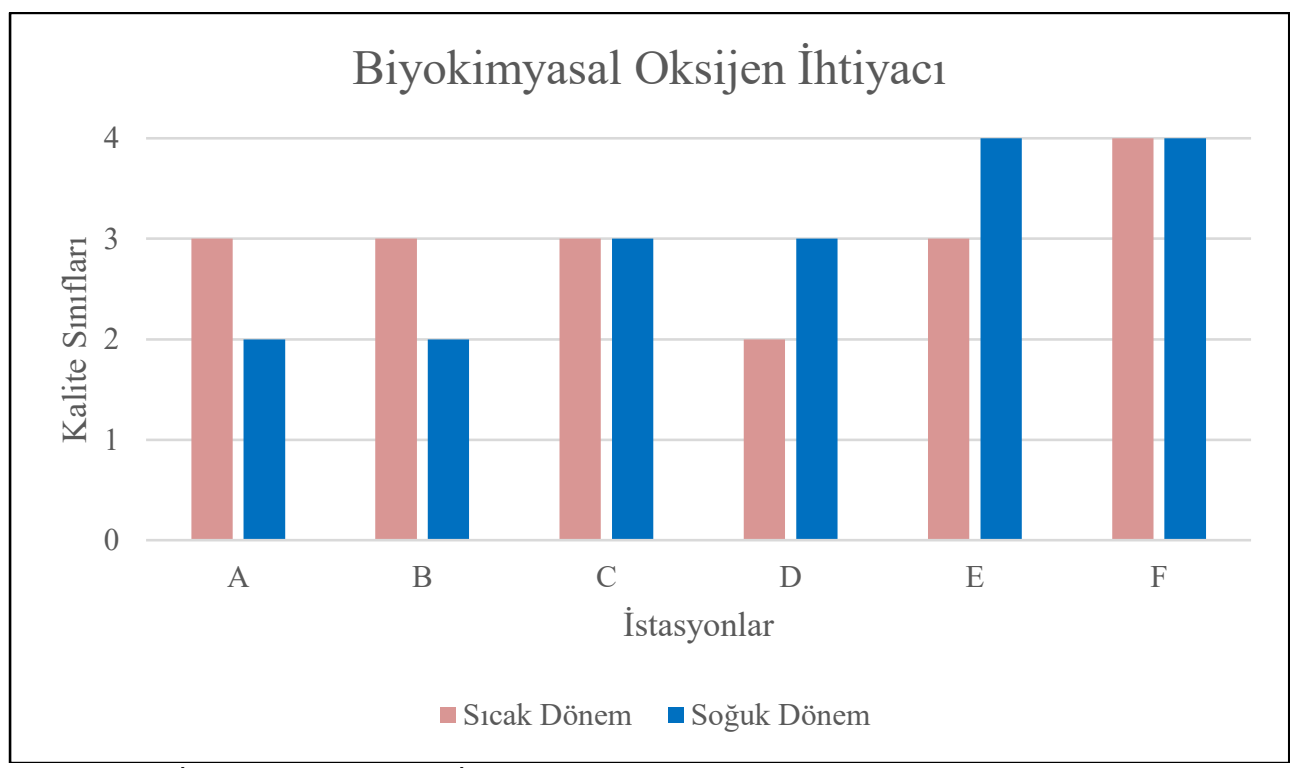

Şekil 7. Su Kalitesi Gözlem İstasyonlarındaki BOİ Değişkenine ait Su Kalite Sınıfları.

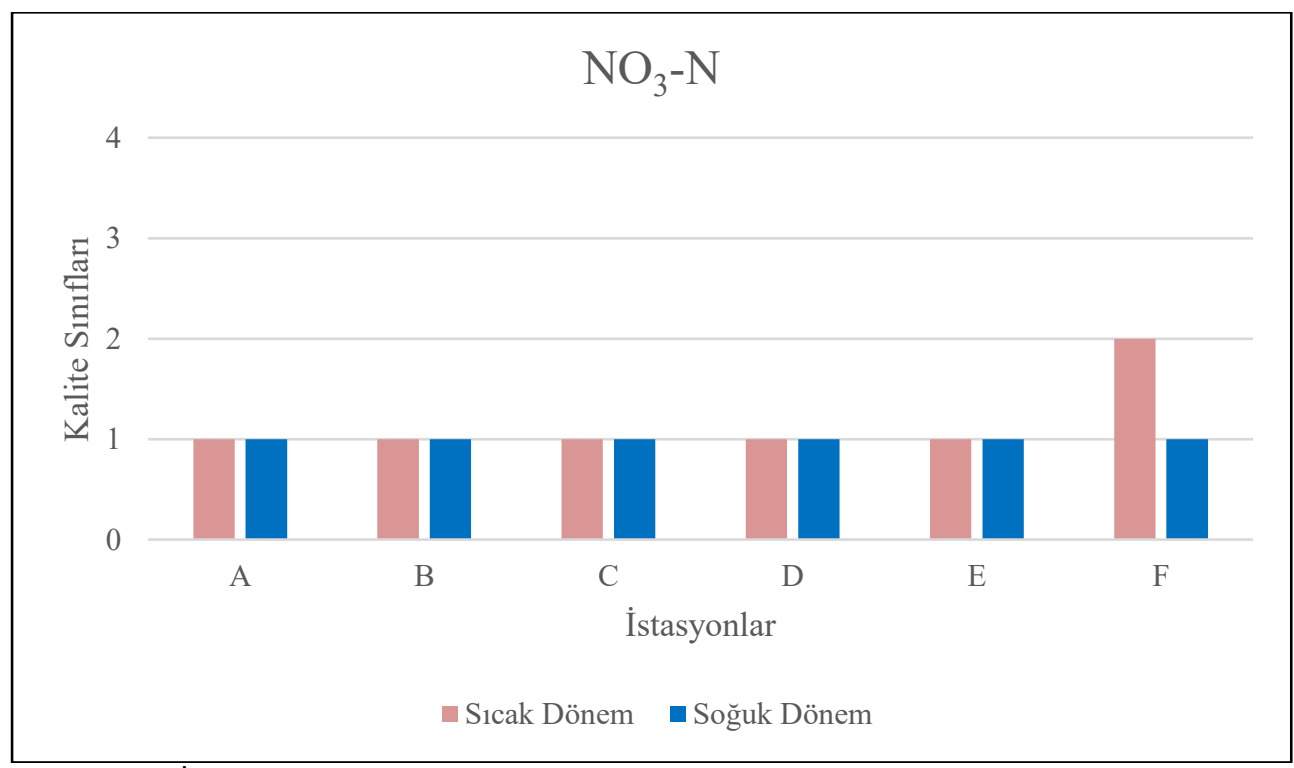

Şekil 8. Su Kalitesi Gözlem İstasyonlarındaki $\mathrm{NO}_{3}-\mathrm{N}$ Değişkenine ait Su Kalite Sınıfları.

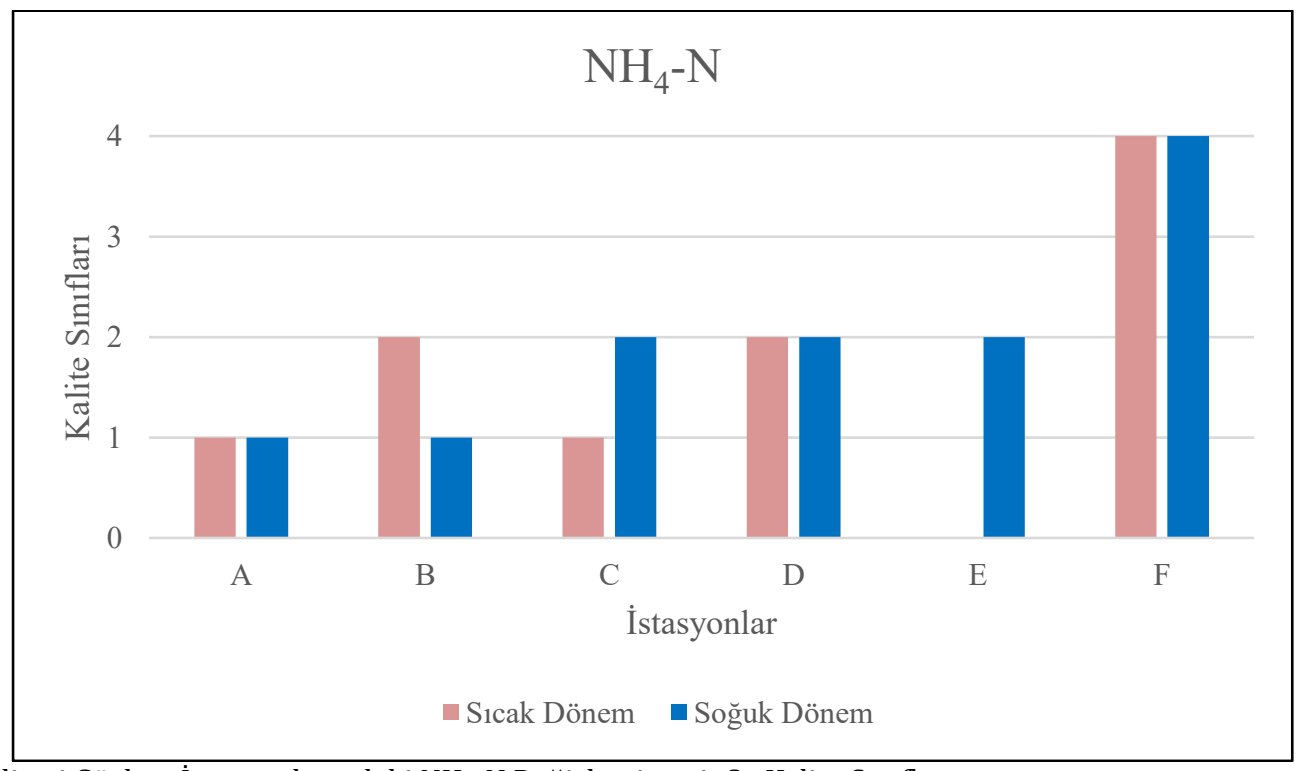

Şekil 9. Su Kalitesi Gözlem İstasyonlarındaki $\mathrm{NH}_{4}-\mathrm{N}$ Değişkenine ait Su Kalite Sınıfları. 
Tablo 4. Standartlaștırılmıș Mann-Kendall İstatistiği Z değerleri ( $\alpha=0,05$ anlamlılık düzeyinde).

\begin{tabular}{|c|c|c|c|c|c|c|c|c|c|c|c|c|}
\hline \multirow{3}{*}{ Değişken } & \multicolumn{12}{|c|}{ İstasyonlar } \\
\hline & \multicolumn{2}{|c|}{$\mathbf{A}$} & \multicolumn{2}{|c|}{ B } & \multicolumn{2}{|c|}{ C } & \multicolumn{2}{|c|}{ D } & \multicolumn{2}{|c|}{$\mathbf{E}$} & \multicolumn{2}{|c|}{$\mathbf{F}$} \\
\hline & Sicak & Soğuk & Sicak & Soğuk & Sicak & Soğuk & Sicak & Soğuk & Sicak & Soğuk & Sicak & Soğuk \\
\hline Sicaklık & 0,627 & 1,642 & $-0,175$ & 1,436 & 1,962 & 4,569 & 2,959 & 2,294 & 3,311 & 4,454 & 2,871 & 5,325 \\
\hline pH & 0,374 & 1,464 & 1,809 & 0,071 & $-0,650$ & 0,078 & $-0,456$ & $-0,332$ & $-2,599$ & $-0,898$ & $-2,020$ & $-0,661$ \\
\hline ÇO & $-1,690$ & $-1,366$ & $-2,424$ & $-2,029$ & $-0,327$ & 1,141 & $-3,913$ & 0,418 & $-0,248$ & 0,192 & $-4,495$ & $-3,666$ \\
\hline BOİ & 3,159 & 1,654 & 1,806 & $-1,139$ & 3,139 & $-0,053$ & 1,624 & $-0,202$ & 1,726 & 0,257 & 4,446 & 5,101 \\
\hline $\mathrm{NO}_{3}-\mathrm{N}$ & 1,981 & 3,704 & 1,387 & 5,027 & 1,236 & 4,657 & 3,982 & 3,741 & 0,632 & 2,863 & 1,526 & 0,420 \\
\hline $\mathrm{NH}_{4}-\mathrm{N}$ & 1,189 & 1,022 & 1,414 & 0,853 & 3,756 & 2,368 & 4,096 & 0,900 & 1,727 & 0,941 & 4,011 & 4,057 \\
\hline & & nlamls & Trend & & & Trer & & & & & & \\
\hline
\end{tabular}

Amonyum ve nitrat açısından dönemler incelendiğinde ise; ortamda ÇO'nin yüksek olduğu durumlarda amonyum iyonlarının nitrifikasyon sürecine girerek nitrat formuna dönüștüğü gözlenmiștir (Șekil 8 ve 9). Nitrat açısından bir istasyon haricinde yüzeysel su I. sınıf kalite özelliğindedir. Düşük akım koşullarında, suda oksijen miktarının çok daha az miktarda olduğu gözlenmiş ve bu durumda nitrata dönüşemeyen azot miktarının amonyum azotu formunda kaldığı görülmüştür. Yan kollarda $\mathrm{pH}$ değerinin 7'den büyük olması ve döngünün tamamlanması için yeterli miktarda da oksijen olması ile yüksek nitrat oluşumu gözlenmektedir. Birleşimden sonra ise, $\mathrm{pH}$ değerinin yine 7'den büyük olmasına rağmen döngünün tamamlanması için yeterli miktarda oksijen olmaması nedeni ile amonyum miktarında artış gözlenmektedir. $\mathrm{F}$ istasyonundaki yüksek $\mathrm{NH}_{4}-\mathrm{N}$ değerleri bunun göstergesidir. $\mathrm{Bu}$ duruma, birleșimden sonra akımdaki artışın da seyrelme ile yeterli ve olumlu katkıda bulunmadığı gözlenmiştir. Ortamdaki oksijen miktarının azalmasina neden olan unsurlar; noktasal ve yayılı kirliliğin derecesinin akarsuyun mansap kısmına doğru ilerledikçe eklenerek artıyor olması ve gerekli arıtma süreçlerinin uygulanmasında eksiklikler olmasıdır. Arazi kullanım haritasında da görüldüğü üzere (Şekil 2), mansap kısmında yerleşim birimlerinin ve buna bağlı noktasal deşarjların yoğunluğu insan kaynaklı kirleticilerin su kalitesi üzerindeki olumsuz etkisini açlklamaktadır.

Mevsimsel farklılıklar incelendiğinde, çalışma bölgesinde kalitenin sıcak dönemlerde olumsuz yönde değiștiği görülmüștür. İklim değişikliği etkisinde değişimin daha kötüye gideceği kaçınılmaz bir gerçektir.

Havzanın genel değerlendirilmesi su kalitesi sınıfları temelinde yapıldıktan sonra, seçilen su kalitesi değişkenlerinin soğuk ve sıcak dönem verileri ile eğilim analizi yapılmış ve hesaplamalar sonucu elde edilen standartlaştırılmış Mann-Kendall istatistiği Z değerleri Tablo 4'te verilmiştir.

Eğilim analizi sonucunda, özellikle akarsudaki organik kirliliğin göstergesi olan ve her iki dönemde de aynı tür eğilimi gösteren değişkenler açısından sonuçlar incelenmiş ve özet bilgiler Tablo 5'te listelenmiştir. BOI, $\mathrm{NO}_{3}-\mathrm{N}$ ve $\mathrm{NH}_{4}-\mathrm{N}$ değişkenleri için, organik faaliyetlerinin yoğun olduğu kısımlarda "Anlamlı Artan"; ÇO değerleri için ise "Anlamlı Azalan" eğilimlerin hesaplandığı gözlenmiştir. Ortaya çıkan anlamlı artan ve azalan eğilimler ilgili istasyonlardaki organik kirliliği işaret ederken, yukarıda belirlenen kalite sınıflarını da destekler niteliktedir.

Tablo 5. Soğuk ve Sıcak Dönemlere ait Eğilim Analiz Sonuçları. İstasyon No. Değişken Sıcak Dönem Soğuk Dönem

\begin{tabular}{|c|c|c|c|}
\hline A & $\mathrm{NO}_{3}-\mathrm{N}$ & + & + \\
\hline B & ÇO & - & - \\
\hline C & $\mathrm{NH}_{4}-\mathrm{N}$ & + & + \\
\hline \multirow[t]{2}{*}{ D } & $\mathrm{NO}_{3}-\mathrm{N}$ & + & + \\
\hline & ÇO & - & - \\
\hline \multirow[t]{2}{*}{$\mathbf{F}$} & BOİ & + & + \\
\hline & $\mathrm{NH}_{4}-\mathrm{N}$ & + & + \\
\hline
\end{tabular}

Her iki dönemde de anlamlı eğilim gösteren değişkenler için, Sen'in Eğilim Eğim Metodu kullanılarak hesaplanan eğim değerleri ise Tablo 6'de listelenmiştir. Hesaplanan eğim değerleri, mevcut su kalitesi durumunun daha detaylı bir şekilde değerlendirilmesine olanak sağlayacaktır.

Tablo 6. Eğilimlerin Eğimleri (birim zamandaki değișim).

İstasyon No. Değişken Sicak Dönem Soğuk Dönem

\begin{tabular}{cccc}
\hline A & $\mathrm{NO}_{3}-\mathrm{N}$ & 0,02337 & 0,02835 \\
\cline { 2 - 4 } B & $\mathrm{C} \mathrm{O}$ & $-0,03333$ & $-0,16167$ \\
\cline { 2 - 4 } C & $\mathrm{NH}_{4}-\mathrm{N}$ & 0,00042 & 0,00120 \\
\cline { 2 - 4 } $\mathbf{D}$ & $\mathrm{NO}_{3}-\mathrm{N}$ & 0,01270 & 0,01900 \\
\cline { 2 - 4 } & $\mathrm{C} O$ & $-0,16429$ & $-0,11667$ \\
& $\mathrm{BOI}$ & 0,60643 & 0,66667 \\
& $\mathrm{NH}_{4}-\mathrm{N}$ & 0,08983 & 0,13727 \\
\hline
\end{tabular}

Tablo 6'daki sonuçlar değerlendirildiğinde, havza çıkışına yakın bir noktada bulunan F istasyonu, özellikle organik faaliyetlerin göstergesi olan ÇO ve BOİ açısından incelendiğinde, ortamdaki oksijen miktarının mikroorganizmalar tarafından kullanılarak tüketildiği açıkça görülmektedir. ÇO ve BOİ için sırasıyla görülen anlamlı azalan ve artan gidișlerin son yıllarda daha da artarak devam ettiği zaman serilerindeki gidişler ile de desteklenmektedir. 2000’li yılların başından itibaren ÇO değerleri azalarak IV. kalite sınıf özelliklerine sahip olurken; buna bağlı 
olarak aynı dönemde BOİ değerleri de artarak yine IV. kalite sınıf su özelliklerini yansıtmaktadır.

Benzer şekilde Tablo 6'daki değerler azot kirliliği açısından değerlendirildiğinde, havzada tarımsal faaliyetler ve ayrıca noktasal deşarjlar kaynaklı azot değerlerinde zamana bağlı artışlar olduğu görülmüştür. $\mathrm{Bu}$ da tarımda gübre kullanımlarının kontrol altına alınması gerekliliğini ortaya koymaktadır. Havza çıkışına en yakın istasyonda " $F$ " hızla artan BOİ değerleri ise kontrolsüz noktasal deşarjların arttığı anlamına gelmektedir. Gözlem istasyonlarında, sudaki azot $\left(\mathrm{NH}_{4}-\mathrm{N}, \mathrm{NO}_{3}-\mathrm{N}\right)$ ve BOİ konsantrasyonlarındaki artışın aksine çözünmüş oksijen değerleri azalan eğilim göstermiştir ki, bu beklenen bir durumdur. Akarsuda bazı bölgelerde zaman zaman gözlenen ani balık ölümlerinin bir sebebi de ÇO açısından gözlenen IV. Sınıf su kalitesi olabilmektedir. Her iki dönemde de azalan eğilimler gözlenmesi, kirliliğinin sucul yaşam açısından kontrol edilmesi gerekliliğini ortaya koymaktadır.

\section{Sonuçlar}

Son yıllarda iklim değişikliği ile azalan yağışlar ve artan insan kaynaklı baskılar (noktasal ve yayılı) su miktarı ile birlikte su kalitesinde de olumsuz etkiler oluşturmaktadır. $\mathrm{Bu}$ nedenle, iklim değişikliğinin meteorolojik koşulları etkilemesiyle birlikte mevsimsel değişikliklere neden olduğu dikkate alındığında, su kalitesindeki mevsimsel değişikliklerin değerlendirilmesi, yüzeysel su kirliliğinin zamansal değişimlerini değerlendirmek açısından önemli olmuştur. Doğa ve insan kaynaklı nedenler ile her mevsimdeki yüzeysel reaksiyonlar farklılıklar göstermekte ve su kalitesindeki mevsimsel değişimin incelenmesi de bu değişimlerin ortaya konması açısından büyük önem taşımaktadır.

$\mathrm{Bu}$ amaçla sunulan çalışmada, Küçük Menderes Havzası'nda su kalitesinin mevsimsel değişimleri, istatistiksel analizler uygulanarak irdelenmeye çalışılmıştır. Su kalitesinin mevcut durumunun değerlendirilebilmesi için "pH", "sıcaklık", "çözünmüş oksijen (ÇO)", "nitrat $\left(\mathrm{NO}_{3}\right)$ azotu", "amonyum $\left(\mathrm{NH}_{4}\right)$ azotu" ve "biyokimyasal oksijen ihtiyacı (BOİ)" değişkenleri seçilmiştir. Bu değişkenler için eğilim testleri, gözlenmiş veriler düşük ve yüksek akım dönemlerine ayrılarak yapılmıştır. "Sicak Dönem" olarak Nisan, Mayıs, Haziran, Temmuz, Ağustos, Eylül, Ekim ayları; "Soğuk Dönem" olarak ise Kasım, Aralık, Ocak, Şubat ve Mart ayları ele alınmıştır. Elde edilen sonuçlarda "anlamlı" bulunan artan ve azalan eğilimler değerlendirmeye alınarak, bu parametreler ve konumlar için daha detaylı incelemeye geçilmiştir.

Yapılan incelemeler sonucunda, 2000'li yılların başından günümüze kadar gözlenen değerlerde anlamlı bir artış olduğu izlenmiştir. Genelde tüm havzada düşük akım koşullarında $\mathrm{pH}$, ÇO, BOİ değişkenleri için III. ve IV. Sınıf su kalitesinin görülmesi, havzadaki evsel ve tarımsal deşarjların göstergesidir. Suyun çeşitli amaçlar için kullanımı mümkün olmayan kalitede olması, havzada kirlilik önleme stratejilerinin gözden geçirilmesi gerekliliğini ortaya koymaktadır.

Tüm bu değerlendirmeler sonucunda, su kalitesi parametrelerinin mevsimsel değişimlerinin incelenmesi, gelecek planlarına temel oluşturulacak etken unsurlardan biri olacaktır. İklim değişikliği ile meteorolojik koşullardaki mevsimsel farklılıkların, benzer şekilde su kalitesinde de izlendiği ve birçok kirlilik önleme planlarının hazırlanmasına alt yapı oluşturacağı sunulan bu çalışma ile öngörülmektedir. Çalışma kapsamında uygulanan yöntem, havza yönetiminde karar verici konumunda olan yetkililer için, havzadaki en etkin kirletici kaynaklarının ve konumlarının belirlenmesinde kolaylık sağlamak ile birlikte; yönetim, idare ve gözlem sistemi kararlarının değerlendirilmesine de destek alt yapı olacaktır.

\section{Teșekkür}

Sunulan çalışma, TÜBİTAK $116 Y 423$ no.lu proje desteğiyle gerçekleştirilmiş olup, yazarlar TÜBİTAK'a teşekkürü bir borç bilirler.

\section{Etik Beyanı}

Bu çalıșmada, "Yükseköğretim Kurumları Bilimsel Araştırma ve Yayın Etiği Yönergesi" kapsamında uyulması gerekli tüm kurallara uyulduğunu, bahsi geçen yönergenin "Bilimsel Araştırma ve Yayın Etiğine Aykırı Eylemler" başlığı altında belirtilen eylemlerden hiçbirinin gerçekleştirilmediğini taahhüt ederiz.

\section{Kaynakça}

[1] Zwart, D., Trivedi, R.C. 1995. Manual on Integrated Water Quality Evaluation, Integral part of project "Biomonitoring Indian rivers 11" under RIVM project number 802023 and DGIS project number 754192 IN/92/021, Directorate General for International Cooperation, Netherlands Ministry of Foreign Affairs.

[2] Gikas, G., Tsihrintzis, V., Akratos, C., Charalampides, G. 2008. Water quality trends in Polyphytos Reservoir, Aliakmon River, Greece. Environmental monitoring and assessment, 149, 163-81.

[3] Leščešen, I., Dolinaj, D., Pantelić, M., Stevan Savić, Dragan Milošević, 2018. Statistical Analysis of Water Quality Parameters in Seven Major Serbian Rivers during 2004-2013 Period. Water Resour $45,418-426$.

[4] Babić, G., Vuković, M., Voza, D., Takić, L., Mladenović-Ranisavljević, I. 2019. Assessing Surface Water Quality in the Serbian Part of the Tisa River Basin. Polish Journal of Environmental Studies, 28(6), 4073-4085. 
[5] Iqbal, M.M., Shoaib, M., Farid, H.U., Lee, J.L. 2018. Assessment of Water Quality Profile Using Numerical Modeling Approach in Major Climate Classes of Asia. International journal of environmental research and public health, 15(10), 2258.

[6] Debels, P., Figueroa, R., Urrutia, R., Barra, R., Niell, X. 2005. Evaluation of Water Quality in the Chillán River (Central Chile) Using Physicochemical Parameters and a Modified Water Quality Index. Environ Monit Assess 110, 301-322.

[7] Massoud, M.A. 2012. Assessment of water quality along a recreational section of the Damour River in Lebanon using the water quality index. Environ Monit Assess 184, 4151-4160.

[8] Gandaseca, S., Rosli, N., Ngayop, J., Arianto, C. 2011. Status of Water Quality Based on the Physico-Chemical Assessment on River Water at Wildlife Sanctuary Sibuti Mangrove Forest, Miri Sarawak. American Journal of Environmental Sciences. 7. 269-275.

[9] Leščešen, I., Pantelić, M., Dolinaj, D., Stojanović, V., Milošević, D. 2015. Statistical Analysis of Water Quality Parameters of the Drina River (West Serbia), 2004-11. Polish Journal of Environmental Studies, 24(2), 555-561.

[10] EC (2013). Improving The Environmental Quality of the Black Sea Through Better Waste Water Treatment \& Climate Change Adaptation of the Water Sector In Moldova, Final Report on Assessing the Impact of Climate Change on Water Supply Sources and Wss Systems in Moldova and Inventory Possible Adaptation Measures (Task 1), European Commission (DG Environment), Organisation for Economic Co-operation and Development (OECD), 70s.

[11] Olds, B.P., Peterson, B.C., Koupal, K.D., Farnsworth-Hoback, K.M., Schoenebeck, C.W., Hoback, W.W. 2011. Water quality parameters of a Nebraska reservoir differ between drought and normal conditions, Lake and Reservoir Management, 27:3, 229-234.

[12] Wang, Y., Bian, J., Zhao, Y., Tang, J., Jia, Z. 2018. Assessment of future climate change impacts on nonpoint source pollution in snowmelt period for a cold area using SWAT. Scientific Reports. 8, 2402.

[13] Delpla, I., Jung, A., Baurès, E., Clement, M., Thomas, 0. 2009. Impacts of climate change on surface water quality in relation to drinking water production. Environment International, $35,1225-1233$.

[14] Kostopoulou, E., Jones, P. 2005. Assessment of climate extremes in the Eastern Mediterranean. Meteorol. Atmos. Phys. 89, 69-85.

[15] Soltani, M., Laux, P., Kunstmann, H., Stan, K., Sohrabi, M.M., Molanejad, M., Sabziparvar, A.A.,
Ranjbar SaadatAbadi, A., Ranjbar, F., Rousta, I., Zawar-Reza, P., Khoshakhlagh, F., Soltanzadeh, I., Babu, C.A., Azizi, G.H., Martin, M.V. 2016. Assessment of climate variations in temperature and precipitation extreme events over Iran. Theor Appl Climatol 126, 775-795.

[16] Yuzhou, L., Ficklin, D.L., Liu, X., Zhang, M. 2013. Assessment of climate change impacts on hydrology and water quality with a watershed modeling approach, Science of The Total Environment, 450-451, 72-82.

[17] O'Farrell, I., Lombardo, R.J., de Tezanos Pinto, P., Loez, C. 2002. The assessment of water quality in the Lower Luján River (Buenos Aires, Argentina): phytoplankton and algal bioassays, Environmental Pollution, 120-2, 207-218.

[18] Shrestha, S., Kazama, F. 2007. Assessment of surface water quality using multivariate statistical techniques: A case study of the Fuji river basin, Japan, Environmental Modelling \& Software, 22-4, 464-475.

[19] Ruggieri, N., Castellano, M., Capello, M., Maggi, S., Povero, P. 2011. Seasonal and spatial variability of water quality parameters in the Port of Genoa, Italy, from 2000 to 2007, Marine Pollution Bulletin, 62-2, 340-349.

[20] Garizi, A.Z., Sheikh, V., Sadoddin, A. 2011. Assessment of seasonal variations of chemical characteristics in surface water using multivariate statistical methods. Int. J. Environ. Sci. Technol. 8, 581-592.

[21] Hughes, M.K., Diaz, H.F. 1994. Was there a 'medieval warm period', and if so, where and when?. Climatic Change 26, 109-142.

[22] Solidoro, C., Pastres, R., Cossarini, G., Ciavatta, S. 2004. Seasonal and spatial variability of water quality parameters in the lagoon of Venice, Journal of Marine Systems, Volume 51, Issues 14, 7-18.

[23] Tokatlı, C., Köse, E., Arslan, N., Emiroğlu, Ö., Çiçek, A., Dayığ̆lu, H. 2016. Emet Çayı Su Kalitesinin Mevsimsel Değișimi. Uludağ University Journal of The Faculty of Engineering, 21, 9.

[24] Doğan Demir, A., Üstün, Ş., Yasin, D. 2016. Murat Nehri Su kalite Parametrelerinin Trend Analizi ve Tarımsal Açıdan Kullanılabilirliği. Yüzüncü Yıl Üniversitesi Tarım Bilimleri Dergisi, 26(3), 414-420.

[25] Yüceer, A., İnkayalı N.G. 2004. Așağı Seyhan Nehri $\mathrm{Su}$ Kalite Değişiminin QUAL2E Modeli İle İncelenmesi, $\mathrm{Su}$ Kirlenmesi Kontrolü Dergisi $14(3), 1-8$.

[26] Baştürk, E., Alver, A. 2019. Melendiz Nehri Su Kalitesinin Farklı Kullanım Amaçlarına Göre Değerlendirilmesi. Ömer Halisdemir Üniversitesi Mühendislik Bilimleri Dergisi. 8 (2), 731-740. 
[27] SYGM, 2018. Küçük Menderes Havzası Kuraklık Yönetim Planı, Cilt I: Havzanın Genel Tanıtımı ve Kuraklı Analizleri, Su Yönetimi Genel Müdürlüğü, Taşkın ve Kuraklık Yönetimi Dairesi Başkanlığı, Ankara, 199s.

[28] SYGM, 2018. Küçük Menderes Havzası Kuraklık Yönetim Planı, Cilt II: Su Bütçesi Çalışmaları, Su Yönetimi Genel Müdürlüğü, Taşkın ve Kuraklık Yönetimi Dairesi Başkanlığı, Ankara, 87s.

[29] SYGM, 2018. Küçük Menderes Havzası Kuraklık Yönetim Planı, Cilt III: Sektörel Etkilenebilirlik Analizleri, Tedbirler ve Eylem Planı, Su Yönetimi Genel Müdürlüğü, Taşkın ve Kuraklık Yönetimi Dairesi Başkanlığı, Ankara, 303s.

[30] SYGM 2019. Küçük Menderes Havzası Nehir Havza Yönetim Planı Hazırlanması Projesi, Nehir Havza Yönetim Planı Nihai Raporu, Su Yönetimi Genel Müdürlüğü, Ankara, 889 s.

[31] MAM 2010. Havza Koruma Eylem Planlarının Hazırlanması Projesi, Küçük Menderes Havzası Nihai Raporu, Cilt I, TÜBİTAK Marmara Araştırma Merkezi Çevre Enstitüsü, Gebze, Kocaeli, 519s.

[32] ÇŞB 2016. Küçük Menderes Havzası Kirlilik Önleme Eylem Planı, T.C Çevre ve Şehircilik Bakanlı̆̆l, Ankara, 68s.

[33] Gündoğdu, V., Özkan, E.Y. 2006. Küçük Menderes Nehri Ölçüm Ağı Tasarımı ve Su Kalite Değişkenlerinin İrdelenmesi Çalışması. Ege Üniversitesi Su Ürünleri Dergisi, 23(3-4), 361-369.

[34] Sütgibi, S. 2009. Küçük Menderes Nehri Delta Ovası ve Degradasyonal Etkiler, Ege Coğrafya Dergisi, 18/(1-2), 59-72, İzmir.

[35] Kurt, S., Haybat, H. 2015. Environmental Geomorphology of the Küçük Menderes River Delta - Küçük Menderes Nehri Deltasının Çevresel Jeomorfolojisi, Route Educational and Social Science Journal, 2(3).

[36] SYGM 2018. Küçük Menderes Nehir Havzası Yönetim Planı, Stratejik Çevresel Değerlendirme Kapsam Belirleme Raporu, Su Yönetimi Genel Müdürlüğü, Ankara, 120s.

[37] Akyüz, Y., Atis, E. 2018. Küçük Menderes Havzasında İklim Değişikliğinin Olası Etkileri ve Üreticilerin Konuya İlişkin Farkındalıkları. Kahramanmaraş Sütçü İmam Üniversitesi Tarım ve Doğa Dergisi 21(Özel Sayı), 109-115.

[38] Tchobanoglous, G., Burton, F.L. 1991. Wastewater engineering: Treatment, disposal and reuse. McGraw-Hill Series, 3rd Edition, Metcalf and Eddy, Inc., 1334s.
[39] Uslu, O., Türkman, A. 1987. Su Kirliliği ve Kontrolü, T.C. Başbakanlık Çevre Genel Müdürlüğü Yayınları Eğitim Dizisi - 1, 364s.

[40] Tebbutt, T.H.Y. 1998. Principles of Water Quality control (Fifth Edition), Butterworth-Heinemann, 288s.

[41] SKKY (2004). Su Kirliliği Kontrolü Yönetmeliği, https://webdosya.csb.gov.tr/db/cygm/icerikler/s u-k-rl-l-g--kontrolu-yonetmel-g-20190104091110.pdf (Erişim Tarihi: 18.03.2020).

[42] SKKY (2008). Su Kirliliği Kontrolü Yönetmeliğinde Değişiklik Yapılmasına Dair Yönetmelik, https://www.resmigazete.gov.tr/eskiler/2008/02 /20080213-13.htm (Erişim Tarihi: 18.03.2020).

[43] Helsel, D.R., Hirsch R.M. 2002. Statistical Methods in Water Resources. Techniques of Water-Resources Investigations of the United States Geological Survey, Book 4, Hydrologic Analysis and Interpretation Chapter 3, U.S. Geological Survey.

[44] Yue, S., Wang, C. 2004. The Mann-Kendall Test Modified by Effective Sample Size to Detect Trend in Serially Correlated Hydrological Series. Water Resources Management 18, 201-218.

[45] Ye, L., Shi, K., Xin, Z., Wang, C., Zhang, C. 2019. Compound Droughts and Heat Waves in China, Sustainability, 11(12), 3270.

[46] Sen P.K. 1968. Estimates of the regression coefficient based on Kendall's tau. J Am Stat As 63:1379-1389.

[47] Karakus, C.B. 2017. Trend Analysis Methods for Hydro-Meteorological Parameters. International Journal of Scientific and Technological Research, $3(2), 22-32$.

[48] Büyükyıldız, M., Berktay, A. 2004. Parametrik Olmayan Testler Kullanılarak Sakarya Havzası Yağışlarının Trend Analizi, S.Ü. Müh.-Mim. Fak. Derg., 19(2).

[49] Gocic, M. and Trajkovic, S. 2013. Analysis of Changes in Meteorological Variables Using MannKendall And Sen's Slope Estimator Statistical Tests in Serbia, Global and Planetary Change, $100,172-182$.

[50] Gilbert R. O. 1987. Statistical Methods for Environmental Pollution Monitoring. Wiley, New York, 336s. 